\title{
The Effect Of IFRS Adoption On Likelihood Of Management Earnings Forecasts: Evidence In Korea
}

\author{
Chang Seop Rhee, Sejong University, Korea ${ }^{1}$ \\ Yong Keun Yoo, Korea University, Korea \\ Seung Min Cha, Kyonggi University, Korea
}

\begin{abstract}
Korean listed companies adopted International financial reporting standards (IFRS) in 2011 mandatorily. The IFRS adoption modifies corporate financial reporting structure and further it can affect managers' incentive for disclosing their earnings forecasts. We investigate the association between IFRS adoption and likelihood of management earnings forecasts. From the empirical results, we find that mandatory IFRS adopted companies are less likely to issue their earnings forecasts after IFRS adoption. It implies that investors'belief about management earnings forecasts as useful information is weakened after IFRS adoption compare to pre-IFRS adoption period. Therefore, managers' incentive for providing earnings forecasts decreases. This study will contribute to academics and disclosure-related practitioners by reporting how IFRS adoption makes an influence to managers' incentive of management earnings forecasts issuance. We also believe that the empirical evidence may shed some lights on the understanding of the spillover effect of IFRS adoption to management earnings forecasts.
\end{abstract}

Keywords: International Financial Reporting Standard; IFRS; Management Earnings Forecasts

\section{INTRODUCTION}

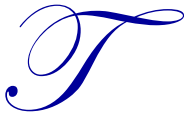

his paper investigates the influence of International Financial Reporting Standards (IFRS) adoption on likelihood of management earnings forecasts in Korea. Through the currency financial crisis of Korea in 1997, Korean financial authorities highlighted the importance of accounting transparency and applied International Accounting Standard(IAS) and IFRS to Korean GAAP (K-GAAP), however they modified some items of IAS and IFRS to fit Korean market conditions. For the reason, foreign investors' credibility of Korean firms' financial statements under K-GAAP was not improved as much as they intended and also Korean discount, the amount by which foreign investors underestimate Korean firm value, was still existed. Hereby, Korean financial authorities prepared to adopt IFRS from 2006 for giving complete faith in accounting transparency to the foreign investors and eliminating Korean discount. Eventually, they decided to conduct mandatory IFRS adoption targeting all listed companies in 2011 and they permit early IFRS adoption in 2009 or 2010 for the companies which want to adopt IFRS voluntarily (Choi and Rhee, 2015).

In this study, we perform Difference-in-Differences (DID) test for controlling time fixed effects at the mandatory IFRS adoption year of $2011^{2}$. In the DID test, we use firms adopted IFRS voluntarily in 2009 or 2010 as a control group and compare them with firms which adopted IFRS mandatorily in 2011. Using 12,897 Korean firm data from 2003 to 2013, we investigate the effect of IFRS adoption on likelihood of management earnings forecasts. From the empirical results, we find that there is a significantly negative association between the years following mandatory IFRS adoption

\footnotetext{
${ }^{1}$ Acknowledgement :This paper is partially drawn from my doctoral dissertation at Korea University. I am very grateful to professor Yong Keun Yoo, my dissertation advisor, for his guidance and help. I also appreciate the supportive comments and suggestions of professor Sung Soo Yoon, Boyoung Moon, Hong Min Chun, and Seung Min Cha.

${ }^{2}$ DID test is the most common statistical technic for controlling the time fixed effect in IFRS study. (Li and Yang, 2016; Ng et al, 2012; Choi, 2013).
}

Copyright by author(s); $\underline{\text { CC-BY }}$ 
of firms mandated IFRS in 2011 and likelihood of management earnings forecasts. The negative association supports the argument that managers are less likely to provide management earnings forecasts after IFRS adoption. On the other hand, there is no significant association between the years following mandatory IFRS adoption of firms adopted IFRS voluntarily in 2009 or 2010 and likelihood of management earnings forecasts. It explains that the reduction phenomenon of management earnings forecasts is the result of mandatory IFRS adoption rather than time fixed effect in 2011. We perform additional tests for examining whether our results may be affected by transitory effect in 2011 and financial crisis effect from 2008 to 2009. From the transitory effect test, we report that the reduction phenomenon of management earnings forecasts is continuously observed after mandatory IFRS adoption in 2011. Also, the negative association between the years following mandatory IFRS adoption of firms mandated IFRS in 2011 and likelihood of management earnings forecasts is still existed after controlling financial crisis effect.

Overall, our empirical results suggest the substitution effect of accounting information from IFRS adoption. IFRS adoption enhances the level of firm's mandatory disclosure, and therefore accounting information users are able to access more accounting information after IFRS adoption. In this circumstance, the usefulness of management earnings forecasts, a type of voluntary disclosure, is weakened, and eventually managers are less likely to provide management earnings forecasts.

This study contributes to the literature in the following ways. First, to our knowledge, there is no previous evidence on the direct negative association between IFRS adoption and likelihood of management earnings forecasts. We believe it will be helpful to academics and disclosure-related practitioners by reporting how IFRS adoption makes an influence to managers' incentive of management earnings forecasts issuance. Next, this study also shows that IFRS adoption affects not only mandatory financial reporting but furthermore voluntary reporting. We also believe that the empirical evidence may shed some lights on the understanding of the spillover effect of IFRS adoption to management earnings forecasts.

The rest of this paper is organized as follow. Section 2 discusses the prior researches and develops our reasoning. Section 3 provides the research design and sample selection criteria. Section 4 reports the empirical results from the model estimation. Section 5 concludes the paper.

\section{BACKGROUND AND HYPOTHESIS DEVELOPMENT}

\subsection{IFRS and Management Earnings Forecasts}

Recent IFRS studies about management earnings forecasts report inconsistent results on the association between IFRS adoption and likelihood of management earnings forecasts. $\mathrm{Ng}$ et al. (2012) studies the influence of IFRS adoption on management earnings forecasts. They use firm data of 18 countries which adopted IFRS and firm data of 17 countries which did not adopted IFRS. After their empirical tests, they report that the firms of IFRS adopted countries are more likely to provide management earnings forecasts than the firms of IFRS un-adopted countries. Especially, likelihood of management earnings forecasts is more pronounced in the countries with strong legal system and regulation. They explain that IFRS is principle based accounting standards and it faces more litigation risks than rule based accounting standards, and therefore firms are more likely to provide management earnings forecasts for reducing litigation risks under IFRS. Also, they argue that market participants request more information under IFRS and therefore firms provide more voluntary information for capital market demand. However, firms listed in foreign markets reduce management earnings forecasts after IFRS adoption.

Li and Yang (2016) analyze firms from 20 countries adopted IFRS mandatorily and firms from 7 countries did not adopted IFRS mandatorily. They report that a significant increase in likelihood of management earnings forecasts after mandatory IFRS adoption. They propose three channels through which IFRS adoption can affect firm's disclosures incentives in response to increased capital market demand. However, they did not find empirical evidence that firms issue more management earnings forecasts after IFRS adoption due to the increased litigation risk.

Firth et al. (2013) consider that the process of Initial Public Offering (IPO) is a setting of high information asymmetry, and they examine the accuracy of management earnings forecasts after IFRS adoption using Australian IPO 
prospectuses data. They report that level of absolute forecasts error of IPO firms is increased after IFRS adoption, and explain the results that management earnings forecasts prepared in accordance with IFRS are difficult to make.

\subsection{Hypothesis Development}

Managers have either an incentive to provide more or less management earnings forecasts after IFRS adoption than before. The incentive to issue less management earnings forecasts are following. $\mathrm{Ng}$ et al. (2012) explain that usefulness of voluntary disclosure information may be weakened as the level of mandatory disclosure information is improved after IFRS adoption. Especially, they reported that managers' incentive to provide less management earnings forecasts are stronger at the firms with relatively high level of mandatory disclosure information. Also, Li and Yang (2016) explain that the circumstance of IFRS which is principle based causes higher litigation risks to companies and therefore managers are less likely to issue management earnings forecasts which include uncertain future performance information for evading litigation risk. Einhorn (2005) argues that managers would like to save the expenses of voluntary disclosure when the level of mandatory disclosure is reinforced, and eventually managers are less likely to provide voluntary disclosures.

On the other hand, the incentive to issue more management earnings forecasts are following. Ng et al. (2012) argue that investors ask for additional information as the volume of mandatory reporting information is increased from IFRS adoption, and therefore managers provide more voluntary disclosure information for the investors. In addition, Li and Yang (2016) suggest that firms have an incentive to issue more management earnings forecasts for inducing a greater number of foreign investors after IFRS adoption.

Thus, it is hard to discern the exact direction of association between IFRS adoption and likelihood of management earnings forecasts. Hence, we set a hypothesis is as follows:

Hypothesis: There is a significant association between Mandatory IFRS adoption and likelihood of management earnings forecasts.

\section{RESEARCH METHODOLOGY}

\subsection{Model Specification}

In this study, we perform DID test for controlling the several institutional effects at the mandatory IFRS adoption period. We use firms which adopted IFRS voluntarily in 2009 or 2010 as a control group and compare them with firms which adopted IFRS mandatorily in 2011. To test our hypothesis on the association between IFRS adoption and likelihood of management earnings forecasts, we construct an indicator variable $(F O C R)$ that equals to 1 if management earnings forecasts are issued, 0 otherwise ( $\mathrm{Ng}$ et al. 2012; Yoo et al. 2013). The dependent variable of FOCR is a dummy variable and therefore we build a logit model below. MAND is an indicator variable whether a firm adopt IFRS mandatorily or voluntarily. Both MPOST and VPOST are indicator variables of the period after IFRS adoption. MPOST is the years following mandatory IFRS adoption of firms mandated IFRS in 2011 while VPOST is the years following mandatory IFRS adoption of firms adopted IFRS voluntarily in 2009 or 2010.

We use control variables of management earnings forecasts determinants. To control the demand of investors for corporate transparency and firms size, we include total number of analysts' following ( $A N A L Y$ ) and natural log of total assets (SIZE) (Rhee and Moon, 2015; Lang and Lundholm, 1993; Kasznik and Lev, 1995). The logarithmic value of market to book ratio $(M B)$ is a control variable for the firm's growth opportunity set (Bamber \& Cheon, 1998). To control a firm's information uncertainty, solvency, and persistence of negative earnings, we include the variables of OIVOL, LEV , and LOSS (Simunic, 1980; Reynold et al., 2001; Hayn, 1995;). We add BIG4 and ACC for controlling auditor quality and potential earnings management (Palmrose, 1986; Dechow et al., 1995; Woo et al., 2015). Additionally, we use CONT to control the effect of a firm' continuous report of consolidated financial statements before mandatory IFRS adoption. 


\section{Model \#1}

$$
\begin{aligned}
& F O C R=\beta_{0}+\beta_{1} M A N D+\beta_{2} M P O S T+\beta_{3} V P O S T+\beta_{4} A N A L Y+\beta_{5} S I Z E+\beta_{6} M B+\beta_{7} \text { OIVOL } \\
& +\beta_{8} L E V+\beta_{9} L O S S+\beta_{10} B I G 4+\beta_{11} A C C+\beta_{12} \text { CONTINUE }+ \text { INDUSTRY }+e
\end{aligned}
$$

where
FOCR
An indicator variable that equals to 1 if a firm issues at least one management earnings forecasts, 0 otherwise.
$M A N D$
An indicator variable that equals to 1 if a firm adopts IFRS mandatorily in 2011, 0 otherwise.
MPOST
An indicator variable that equals to 1 if a firm adopts IFRS mandatorily and year is 2011 or after, 0 otherwise.
VPOST An indicator variable that equals to 1 if a firm adopts IFRS voluntarily and year is 2011 or after, 0 otherwise.
ANALY The total number of analysts' following.
SIZE Natural log of total assets.
$M B \quad$ The logarithmic value of market to book ratio
OIVOL The standard deviation of operating income scaled by average total assets.
LEV Total leverage scaled by total assets.
LOSS An indicator variable that equals to 1 if a firm reports a loss in the current period, 0 otherwise
BIG4 An indicator variable that equals to 1 if a firm hires a Big4 auditor, 0 otherwise.
$A C C \quad$ Accrual; a measure of firm-level financial transparency.
CONT An indicator variable that equals to 1 if a firm provide consolidated financial statements continuously before mandatory IFRS adoption.
INDUSTRY Industry dummy variables.

\subsection{Sample Selection}

Our empirical tests are based on 12,897 Korean firm-year observations from 2003 to 2013 fiscal year, which satisfy the following selection criteria: (1) financial statement data with a positive book value of equity available on Kis Value database; (2) all of the proxies are available; (3) firms in non-financial industry; (4) fiscal year ended December 31 . $^{3}$ We collect the information of management earnings forecasts from Data Analysis, Retrieval and Transfer System (DART) of Financial Supervisory Service in Korea. Table 1 shows the sample distribution of the final firm-year observations for our empirical tests. We present the observations by fiscal year in Panel A and the observations by industry group in Panel B. In Panel A of Table 1, 14.10\% of total sample provided management earnings forecasts while $85.90 \%$ did not. All Korean listed companies were required to adopt IFRS in 2011 mandatorily. If they requested to adopt IFRS in advance, they were able to adopt IFRS either in 2009 or 2010 voluntarily. Panel B shows that manufacturing industry occupies the largest portion of $70.94 \%$ in the total sample.

\footnotetext{
${ }^{3}$ This study sets up the testing periods from 2003 because Korean listed companies actively adopted K-GAAP which was established by IFRS basis from 2003.

Copyright by author(s); $\underline{\mathrm{CC}-\mathrm{BY}}$ 
Table 1. Sample Distribution

\begin{tabular}{|c|c|c|c|c|c|c|c|c|c|c|c|}
\hline \multicolumn{12}{|c|}{ Panel A Sample distribution by fiscal year } \\
\hline \multirow{3}{*}{ Year } & \multicolumn{5}{|c|}{ Management Earnings forecasts Issued } & \multicolumn{5}{|c|}{ Management Earnings forecasts Un-issued } & \multirow{3}{*}{ Total } \\
\hline & \multicolumn{2}{|c|}{$\begin{array}{c}\text { Mandatory } \\
\text { Adoption }\end{array}$} & \multicolumn{2}{|c|}{$\begin{array}{l}\text { Voluntary } \\
\text { Adoption }\end{array}$} & \multirow[t]{2}{*}{ Subtotal } & \multicolumn{2}{|c|}{$\begin{array}{l}\text { Mandatory } \\
\text { Adoption }\end{array}$} & \multicolumn{2}{|c|}{$\begin{array}{l}\text { Voluntary } \\
\text { Adoption }\end{array}$} & \multirow[t]{2}{*}{ Subtotal } & \\
\hline & GAAP & IFRS & GAAP & IFRS & & GAAP & IFRS & GAAP & IFRS & & \\
\hline 2003 & 79 & & 5 & & $\begin{array}{c}84 \\
(9.46 \%)\end{array}$ & 773 & & 31 & & $\begin{array}{c}804 \\
(90.54 \%)\end{array}$ & $\begin{array}{c}888 \\
(100.00 \%)\end{array}$ \\
\hline 2004 & 119 & & 6 & & $\begin{array}{c}125 \\
(13.13 \%)\end{array}$ & 791 & & 36 & & $\begin{array}{c}827 \\
(86.87 \%)\end{array}$ & $\begin{array}{c}952 \\
(100.00 \%)\end{array}$ \\
\hline 2005 & 202 & & 9 & & $\begin{array}{c}211 \\
(20.93 \%)\end{array}$ & 760 & & 37 & & $\begin{array}{c}797 \\
(79.07 \%)\end{array}$ & $\begin{array}{c}1,008 \\
(100.00 \%)\end{array}$ \\
\hline 2006 & 226 & & 10 & & $\begin{array}{c}236 \\
(22.04 \%)\end{array}$ & 800 & & 35 & & $\begin{array}{c}835 \\
(77.96 \%)\end{array}$ & $\begin{array}{c}1,071 \\
(100.00 \%)\end{array}$ \\
\hline 2007 & 226 & & 9 & & $\begin{array}{c}235 \\
(20.56 \%)\end{array}$ & 868 & & 40 & & $\begin{array}{c}908 \\
(79.44 \%)\end{array}$ & $\begin{array}{c}1,143 \\
(100.00 \%)\end{array}$ \\
\hline 2008 & 196 & & 9 & & $\begin{array}{c}205 \\
(16.75 \%)\end{array}$ & 981 & & 38 & & $\begin{array}{c}1,019 \\
(83.25 \%)\end{array}$ & $\begin{array}{c}1,224 \\
(100.00 \%)\end{array}$ \\
\hline 2009 & 147 & & 6 & 2 & $\begin{array}{c}155 \\
(12.08 \%)\end{array}$ & 1,082 & & 35 & 11 & $\begin{array}{c}1,128 \\
(87.92 \%)\end{array}$ & $\begin{array}{c}1,283 \\
(100.00 \%)\end{array}$ \\
\hline 2010 & 155 & & & 4 & $\begin{array}{c}159 \\
(11.80 \%)\end{array}$ & 1,140 & & & 49 & $\begin{array}{c}1,189 \\
(88.20 \%)\end{array}$ & $\begin{array}{c}1,348 \\
(100.00 \%)\end{array}$ \\
\hline 2011 & & 153 & & 6 & $\begin{array}{c}159 \\
(11.34 \%)\end{array}$ & & 1,195 & & 48 & $\begin{array}{c}1,243 \\
(88.66 \%)\end{array}$ & $\begin{array}{c}1,402 \\
(100.00 \%)\end{array}$ \\
\hline 2012 & & 175 & & 11 & $\begin{array}{c}186 \\
(12.79 \%)\end{array}$ & & 1,223 & & 45 & $\begin{array}{c}1,268 \\
(87.21 \%)\end{array}$ & $\begin{array}{c}1,454 \\
(100.00 \%)\end{array}$ \\
\hline 2013 & & 58 & & 5 & $\begin{array}{c}63 \\
(5.60 \%)\end{array}$ & & 1,023 & & 38 & $\begin{array}{c}1,061 \\
(94.40 \%)\end{array}$ & $\begin{array}{c}1,124 \\
(100.00 \%)\end{array}$ \\
\hline \multirow{2}{*}{ Total } & 1,350 & 386 & 54 & 28 & \multirow{2}{*}{$\begin{array}{c}1,818 \\
(14.10 \%)\end{array}$} & 7,195 & 3,441 & 252 & 191 & \multirow{2}{*}{$\begin{array}{c}11,079 \\
(85.90 \%)\end{array}$} & \multirow{2}{*}{$\begin{array}{c}12,897 \\
(100.00 \%)\end{array}$} \\
\hline & & & & & & & & & & & \\
\hline
\end{tabular}

Panel B. Sample distribution by Industry

\begin{tabular}{l|r|r}
\hline \multicolumn{1}{c|}{ Industry } & Number of Observations & Percentage (\%) \\
\hline Agriculture, forestry, and fishery & 44 & 0.34 \\
\hline Mining & 20 & 0.16 \\
\hline Manufacturing & 9,149 & 0.94 \\
\hline Electricity, gas, steam and water supply & 113 & 0.38 \\
\hline Environmental service & 39 & 3.97 \\
\hline Construction & 513 & 6.53 \\
\hline Wholesale and retail trade & 842 & 1.83 \\
\hline Transportation & 236 & 0.09 \\
\hline Lodging and restaurant & 11 & 8.97 \\
\hline $\begin{array}{l}\text { Publishing, broadcasting, and media } \\
\text { service }\end{array}$ & 1,157 & 0.16 \\
\hline Real estate and leasing service & 21 & 3.78 \\
\hline $\begin{array}{l}\text { Professional, scientific and technical } \\
\text { activities }\end{array}$ & 489 & 1.04 \\
\hline Facilities management and supporting & 134 & 0.49 \\
\hline service & 63 & 0.43 \\
\hline Education service & 55 & 0.09 \\
\hline Art, sports, and recreation service & 11 & 100.00 \\
\hline Organization, and other personal service & 12,897 & \\
\hline Total & & \\
\hline
\end{tabular}




\section{EMPIRICAL RESULTS}

\subsection{Descriptive Statistics}

Table 2 provides descriptive statistics about likelihood of management earnings forecasts, IFRS adoption related variables, and other control variables. The mean of management earnings forecasts likelihood $(F O C R)$ is 0.141 which indicates that average $14.10 \%$ of companies issue management earnings forecasts. MAND, MPOST, and VPOST are IFRS adoption related variables. The mean of MAND is 0.959 implies that $95.9 \%$ Korean listed companies adopt IFRS mandatorily in 2011. The mean of MPOST and VPOST are 0.297 and 0.012 respectively. It suggests that average $29.7 \%$ Korean listed companies that adopted IFRS mandatorily issue management earnings forecasts after IFRS adoption year of 2011 while $0.012 \%$ Korean listed companies that adopted IFRS voluntarily issue management earnings forecasts after the year. Distribution of the other control variables is generally consistent with prior Korean studies.

Table 2. Statistics Description

\begin{tabular}{l|c|c|c|c|c|c|c|c}
\hline Variables & Mean & Std. & $\mathbf{1 \%}$ & $\mathbf{2 5 \%}$ & $\mathbf{5 0 \%}$ & $\mathbf{7 5 \%}$ & $\mathbf{9 9 \%}$ & Obs. \\
\hline FOCR & 0.141 & 0.348 & 0.000 & 0.000 & 0.000 & 0.000 & 1.000 & 12,897 \\
\hline MAND & 0.959 & 0.198 & 0.000 & 1.000 & 1.000 & 1.000 & 1.000 & 12,897 \\
\hline MPOST & 0.297 & 0.457 & 0.000 & 0.000 & 0.000 & 1.000 & 1.000 & 12,897 \\
\hline VPOST & 0.012 & 0.108 & 0.000 & 0.000 & 0.000 & 0.000 & 1.000 & 12,897 \\
\hline ANALY & 0.334 & 2.193 & 0.000 & 0.000 & 0.000 & 0.000 & 14.000 & 12,897 \\
\hline SIZE & 24.944 & 1.514 & 22.293 & 23.914 & 24.689 & 25.652 & 29.857 & 12,897 \\
\hline MB & 1.288 & 1.232 & 0.173 & 0.554 & 0.899 & 1.549 & 7.672 & 12,897 \\
\hline OIVOL & 0.047 & 0.045 & 0.003 & 0.019 & 0.034 & 0.059 & 0.247 & 12,897 \\
\hline LEV & 0.461 & 0.262 & 0.040 & 0.262 & 0.441 & 0.617 & 1.391 & 12,897 \\
\hline LOSS & 0.251 & 0.434 & 0.000 & 0.000 & 0.000 & 1.000 & 1.000 & 12,897 \\
\hline BIG4 & 0.542 & 0.498 & 0.000 & 0.000 & 1.000 & 1.000 & 1.000 & 12,897 \\
\hline ACC & -0.031 & 0.119 & -0.528 & -0.076 & -0.021 & 0.027 & 0.284 & 12,897 \\
\hline CONT & 0.493 & 0.500 & 0.000 & 0.000 & 0.000 & 1.000 & 1.000 & 12,897 \\
\hline
\end{tabular}

\subsection{Univariate Analysis}

Table 3 presents the Pearson correlations among likelihood of management earnings forecasts (FOCR), IFRS adoption related variables (MAND, MPOST, and VPOST) and other variables. In table 3, FOCR is negatively correlated with $M P O S T$, and it implies that mandatory IFRS adopted companies are less likely to provide management earnings forecasts after IFRS adoption. On the other hand, there is no significant between FOCR and VPOST that suggests IFRS adoption does not make a significant influence on management earnings forecasts likelihood of voluntary IFRS adopted companies. However, as the implication of the univariate result appears to be limited, we perform the multivariate logit analyses to examine the overall association between likelihood of management earnings forecasts $(F O C R)$ and IFRS adoption related variables (MAND, MPOST, and VPOST) coupled with control variables in section 4.3. Most control variables are correlated each other as expected. 
Table 3. Univariate Correlation among the Main Variables

\begin{tabular}{|c|c|c|c|c|c|c|c|c|c|c|c|c|}
\hline & FOCR & $M A N D$ & MPOST & VPOST & ANALY & SIZE & $M B$ & OIVOL & $L E V$ & LOSS & BIG4 & $A C C$ \\
\hline MAND & -0.009 & & & & & & & & & & & \\
\hline MPOST & -0.075 & 0.134 & & & & & & & & & & \\
\hline VPOST & 0.001 & -0.532 & -0.071 & & & & & & & & & \\
\hline$A N A L Y$ & 0.096 & -0.117 & 0.170 & 0.186 & & & & & & & & \\
\hline SIZE & 0.273 & -0.106 & 0.046 & 0.064 & 0.361 & & & & & & & \\
\hline$M B$ & 0.140 & -0.037 & 0.031 & 0.013 & 0.099 & 0.258 & & & & & & \\
\hline OIVOL & -0.015 & 0.003 & -0.050 & -0.019 & -0.050 & -0.143 & 0.275 & & & & & \\
\hline$L E V$ & 0.087 & -0.016 & -0.039 & 0.006 & 0.013 & 0.038 & 0.111 & 0.068 & & & & \\
\hline LOSS & -0.100 & -0.003 & 0.031 & 0.008 & -0.047 & -0.224 & 0.087 & 0.256 & 0.116 & & & \\
\hline$B I G 4$ & 0.114 & -0.027 & 0.021 & 0.025 & 0.116 & 0.335 & 0.011 & -0.081 & 0.013 & -0.089 & & \\
\hline$A C C$ & 0.039 & 0.019 & 0.015 & -0.002 & 0.024 & 0.102 & -0.066 & -0.189 & -0.058 & -0.401 & 0.032 & \\
\hline CONT & 0.076 & -0.042 & -0.059 & 0.019 & 0.093 & 0.314 & -0.052 & -0.148 & 0.091 & -0.047 & 0.155 & 0.016 \\
\hline Obs. & 12,897 & 12,897 & 12,897 & 12,897 & 12,897 & 12,897 & 12,897 & 12,897 & 12,897 & 12,897 & 12,897 & 12,897 \\
\hline
\end{tabular}

Note: Bold numbers indicate the significance level at 5 percent levels or better (two-tailed).

\subsection{Multivariate Analysis}

Table 4 presents the results from a multivariate logit analysis for investigating the effect of IFRS adoption on likelihood of management earnings forecasts. In Panel A, likelihood of management earnings forecasts (FOCR) is positively associated with the companies that adopted IFRS mandatorily $(M A N D)$ at one percent or less of significance level ( $\mathrm{t}$ stat=3.40). On the other hand, it is negatively associated with the years following mandatory IFRS adoption of firms mandated IFRS in 2011 (MPOST) at one percent or less of significance level ( $\mathrm{t}$-stat=-0.660). These positive and negative associations suggest that the firms adopted IFRS mandatorily are more likely to issue management earnings forecasts before IFRS adoption but they changed to reduce the issuance of manage earnings forecasts after IFRS adoption. We interpret that the results as the substitution effect of accounting information from IFRS adoption. IFRS adoption enhanced the level of firm's mandatory disclosure, and therefore accounting information users are able to access more accounting information after IFRS adoption. In this circumstance, the usefulness of management earnings forecasts is reduced and eventually managers are less likely to provide management earnings forecasts.

In addition, there is no significant association between the years following mandatory IFRS adoption of firms adopted IFRS voluntarily in 2009 or 2010 (VPOST) and likelihood of management earnings forecasts (FOCR). The reduction phenomenon of management earnings forecasts after 2011 is not observed from voluntary IFRS adopters. It supports the argument that the reduction phenomenon of management earnings forecasts is the result of IFRS adoption rather than time fixed effect in 2011. Specifically, Panel B presents the difference between pre-IFRS period and post-IFRS period. Firms adopted IFRS mandatorily in 2011 show the significant difference, but firms adopted IFRS voluntarily in 2009 or 2010 do not. Also, before 2011 there is significant difference between firms adopted IFRS mandatorily and firms adopted IFRS voluntarily, but after 2011 there is no significant difference between them. Those results in Panel $\mathrm{B}$ also support that mandatory IFRS adoption affect the reduction of management earnings forecasts. 
Table 4. Management earnings forecasts likelihood and IFRS adoption

\begin{tabular}{|c|c|c|}
\hline \multirow{2}{*}{ Independent Variable } & \multicolumn{2}{|c|}{ Dependent Variable: FOCR } \\
\hline & Coef. & t-stat. \\
\hline INTERCEPT & $-13.291 * * *$ & -21.69 \\
\hline$M A N D$ & $0.543 * * *$ & 3.40 \\
\hline MPOST & $-0.660 * * *$ & -9.63 \\
\hline VPOST & -0.229 & -0.76 \\
\hline$A N A L Y$ & 0.011 & 1.07 \\
\hline$\overline{S I Z E}$ & $0.396 * * *$ & 18.90 \\
\hline$M B$ & $0.147 * * *$ & 6.97 \\
\hline OIVOL & 0.414 & 0.63 \\
\hline$L E V$ & $0.780 * * *$ & 7.63 \\
\hline LOSS & $-0.532 * * *$ & -6.58 \\
\hline$B I G 4$ & $0.234 * * *$ & 3.84 \\
\hline$A C C$ & 0.203 & 0.82 \\
\hline CONTINUE & -0.075 & -1.25 \\
\hline Industry Dummy & \multicolumn{2}{|c|}{ Included } \\
\hline Pseudo R2 & \multicolumn{2}{|c|}{$11.65 \%$} \\
\hline Number of Observations & \multicolumn{2}{|c|}{12,897} \\
\hline
\end{tabular}

Panel B. Two-by-Two Analysis: Mandatory IFRS adopted firms Vs. Voluntary IFRS adopted firms

\begin{tabular}{l|c|c|c}
\hline & Pre-IFRS (2003 2010) & Post-IFRS (2011 2013) & Difference \\
\hline Mandatory IFRS adopted firms & -12.748 & -13.407 & $-0.660^{* * *}$ \\
\hline Voluntary IFRS adopted firms & -13.291 & -13.520 & -0.229 \\
\hline Difference & $-0.543^{* * *}$ & -0.112 & -0.431 \\
\hline
\end{tabular}

\subsection{Additional Tests}

We test whether the reduction phenomenon of management earnings forecasts after 2011 is affected by transitory effect or financial crisis effect considerably. In Table 5, we add the interaction terms between firms adopted IFRS mandatorily and years dummy variables after IFRS mandatory adoption $(M A N D * Y E A R 2011, M A N D * Y E A R 2012$, and $M A N D * Y E A R 2013$ ) for controlling transitory effect. We observed the negatively significant association from all three interaction terms, and it means that the reduction phenomenon of management earnings forecasts persisted after IFRS mandatory adoption. From the additional test 1, we can conclude that the reduction phenomenon is not a result of transitory effect in 2011 .

Additionally, to test whether financial crisis exerts a significant influence on the reduction of management earnings forecasts, we perform the regression and DID tests excluding samples of financial crisis years (2008 and 2009) in Table 6 . The result of Table 6 is still consistent with the result of the main test in Table 5 even after controlling financial crisis effect. Therefore, we can conclude that the reduction phenomenon is not depended on financial crisis effect. 
Table 5. Additional Test 1: Controlling Transitory Effect

\begin{tabular}{|c|c|c|}
\hline \multirow{2}{*}{ Independent Variable } & \multicolumn{2}{|c|}{ Dependent Variable: $F O C R$} \\
\hline & Coef. & t-stat. \\
\hline INTERCEPT & $-13.247 * * *$ & $(-21.898)$ \\
\hline MAND & $0.595^{* * *}$ & $(4.257)$ \\
\hline$M A N D \times Y E A R 2011$ & $-0.602 * * *$ & $(-6.161)$ \\
\hline$M A N D \times Y E A R 012$ & $-0.453 * * *$ & $(-4.807)$ \\
\hline$M A N D \times Y E A R 2013$ & $-1.162 * * *$ & $(-8.033)$ \\
\hline$A N A L Y$ & 0.009 & $(0.915)$ \\
\hline SIZE & $0.393 * * *$ & $(18.666)$ \\
\hline$\overline{M B}$ & $0.147 * * *$ & $(7.014)$ \\
\hline OIVOL & 0.366 & $(0.564)$ \\
\hline$L E V$ & $0.768 * * *$ & $(7.546)$ \\
\hline LOSS & $-0.538 * * *$ & $(-6.648)$ \\
\hline$B I G 4$ & $0.238 * * *$ & $(3.902)$ \\
\hline$\overline{A C C}$ & 0.190 & $(0.778)$ \\
\hline CONTINUE & -0.075 & $(-1.238)$ \\
\hline Industry Dummy & \multicolumn{2}{|c|}{ Included } \\
\hline Pseudo R2 & \multicolumn{2}{|c|}{$11.85 \%$} \\
\hline Number of Observations & \multicolumn{2}{|c|}{12,897} \\
\hline
\end{tabular}

Table 6. Additional Test 2: Controlling Financial Crisis effect

Panel A. Results of Multivariate Logit Analysis

\begin{tabular}{|c|c|c|}
\hline \multirow{2}{*}{ Independent Variable } & \multicolumn{2}{|c|}{ Dependent Variable: $F O C R$} \\
\hline & Coef. & t-stat. \\
\hline$\overline{I N T E R C E P T}$ & $-13.443 * * *$ & -19.18 \\
\hline MAND & $0.595 * * *$ & 3.18 \\
\hline MPOST & $-0.697 * * *$ & -9.79 \\
\hline VPOST & -0.212 & -0.67 \\
\hline$A N A L Y$ & 0.013 & 1.24 \\
\hline SIZE & $0.399 * * *$ & 16.73 \\
\hline$\overline{M B}$ & $0.128 * * *$ & 5.29 \\
\hline OIVOL & 0.889 & 1.24 \\
\hline$\overline{L E V}$ & $0.808 * * *$ & 7.05 \\
\hline LOSS & $-0.589 * * *$ & -6.29 \\
\hline$B I G 4$ & $0.176^{* * *}$ & 2.60 \\
\hline$A C C$ & 0.348 & 1.24 \\
\hline CONTINUE & -0.083 & -1.22 \\
\hline INDUSTRY DUMMY & \multicolumn{2}{|c|}{ Included } \\
\hline Pseudo R2 & \multicolumn{2}{|c|}{$11.63 \%$} \\
\hline Number of Observations & \multicolumn{2}{|c|}{10,390} \\
\hline
\end{tabular}

Note: t-statistics are reported in bracket. ${ }^{* *},{ }^{* *}, *$ indicate, respectively, the significance level at the $1 \%, 5 \%$ and $10 \%$ level or better.

Panel B. Two-by-Two Analysis: Mandatory IFRS adopted firms Vs. Voluntary IFRS adopted firms

\begin{tabular}{l|c|c|c}
\hline & Pre-IFRS (2003 2010) & Post-IFRS (2011 2013) & Difference \\
\hline Mandatory IFRS adopted firms & -12.848 & -13.545 & $-0.697 * * *$ \\
\hline Voluntary IFRS adopted firms & -13.443 & -13.655 & -0.212 \\
\hline Difference & $-0.595^{* * *}$ & -0.110 & -0.485 \\
\hline
\end{tabular}




\section{CONCLUSION}

This study examines the association between IFRS adoption and likelihood of management earnings forecasts. It provides evidences as to whether mandatory IFRS adoption in Korea affects to managers' incentive of voluntary disclosure. We find that mandatory IFRS adopted companies are less likely to issue their earnings forecasts after mandatory IFRS adoption in Korea. It implies that investor's belief about management earnings forecasts as useful information is weakened after IFRS adoption compare to pre-IFRS adoption period.

Nonetheless, we acknowledge that our findings may have following caveats. First, there may be other omitted factors which bias our empirical results. We cannot rule out the possibility that our results largely depend on measurement criteria. Second, this is an early study of IFRS adoption effect in Korea and the post IFRS period of our firm-year observations is only three years in this study. Therefore, it is challenging to say that our result can last for a length period of time.

Despite these caveats, this study will contribute to academics and disclosure-related practitioners by reporting how IFRS adoption makes an influence to managers' incentive of management earnings forecasts issuance. We also believe that the empirical evidence may shed some lights on the understanding of the spillover effect of IFRS adoption to management earnings forecasts.

\section{AUTHOR BIOGRAPHIES}

Chang Seop Rhee is an assistant professor at Sejong University in Korea $\left(1^{\text {st }}\right.$ Author $)$.

Yong Keun Yoo is a professor at Korea University in Korea (Corresponding Author).

Seung Min Cha is an associate professor at Kyonggi University in Korea (Co-Author).

\section{REFERENCES}

Bamber, L. S. \& Y. S. Cheon. (1998). Discretionary management earnings forecast disclosures: antecedents and outcomes associated with forecast venues and forecast specificity choices. Journal of Accounting Research, 36(Autumn), 167190.

Choi, E. S. (2013). IFRS adoption and cost of equity capital: Korean evidence. Working paper.

Dechow, P. M., R. G. Sloan, \& A. P. Sweeney. (1995). Detecting earnings management. The Accounting Review, 70(2), $193-225$.

Einhorn, Eti. (2005). The nature of the interaction between mandatory and voluntary disclosures. Journal of Accounting Research, 43(4), 593-621.

Firth, M., D. Gounopoulos, \& J. Pulm. (2013). IFRS adoption and management earnings forecasts of Australian IPOs. Working paper.

Hayn, C. (1995). The information content of losses. Journal of Accounting and Economics, 20(2), 125-153.

Kasznik, R., \& B. Lev. (1995). To warn or not to warn: Management disclosures in the face of an earnings surprise. The Accounting Review, 70(1), 113-134.

Lang, M., \& R. Lundholm. (1993). Cross-sectional determinants of analyst ratings of corporate disclosures. Journal of Accounting Research, 31(2), 246-271.

Li, Xi., \& H. Yang. (2016). Mandatory financial reporting and voluntary disclosure: The effect of mandatory IFRS adoption on management forecasts. The Accounting Review, 91(3), 933-953.

Ng, J., A. Tsang. \& Y. G. Yang. (2012). Mandatory IFRS adoption and management forecasts. Working paper.

Palmrose, Z. (1986). The effect of nonaudit services on the pricing of audit services: Further evidences, Journal of Accounting Research, 24(Autumn), 405-411.

Reynold, J. L., Deis, D. \& Francis, J. R. (2004). Professional service fees and auditor objectivity, Auditing: A Journal of Practice \& Theory, 23, 29-52.

Rhee, C., \& B. Moon. (2015). New chief executive officers' earnings forecasts bias at their first year term and role of financial analysts: Korean evidence. The Journal of Applied Business Research, 31(4), 1267-1276.

Simunic, D. A. (1980). The pricing of audit services: Theory and evidences, Journal of Accounting Research, 18(1), 161-190.

Yoo, G., S. Cha, Y. Yoo, \& C. Rhee. (2013). Management earnings forecasts and cost of equity capital: Korean evidence. Korean Accounting Review, 38(1), 209-243.

Woo, S., C. Rhee, S. Woo. (2015). The effect of directors and officers liability insurance on audit effort. The Journal of Applied Business Research, 31(6), 1039-1046.

Copyright by author(s); $\underline{\text { CC-BY }}$ 